\title{
Entre quehaceres conventuales y arrebatos místicos: el Diario Espiritual de Úrsula de Jesús (Lima, siglo XVII)*
}

\section{Between Convent Chores and Mystical Raptures: The Spiritual Diary of Ursula de Jesus (Lima, Seventeenth Century)}

GIOVANNA PIGNANO BRAVO

Pontificia Universidad Católica del Perú

gpignano@pucp.pe

\section{RESUMEN}

El presente artículo estudia el caso de la donada negra Úrsula de Jesús (Lima, 1604-1666), cuya excepcional religiosidad ha sido retratada por un franciscano y una clarisa anónimos. Ella vivió la mayor parte de su vida al interior del monasterio de Santa Clara, al cual ingresó como esclava de una monja de velo negro. Posteriormente, consiguió su libertad y, apoyada por algunas monjas, profesó como donada y, además, escribió un Diario Espiritual en el que contó su vida cotidiana en el monasterio y las vicisitudes de su espiritualidad. Si bien se tiene conocimiento de otros afrodescendientes que fueron reconocidos por su piedad católica, solo los conocemos a través del discurso dominante que moldeó sus particulares experiencias espirituales para hacerlas calzar con los modelos de santidad occidentales. En este caso, sucede lo contrario: el Diario Espiritual

* Este artículo se basa en la tesis para optar por el título de licenciada en Historia en la Pontificia Universidad Católica del Perú. Agradezco a los lectores anónimos por sus sugerencias. 
nos permite oir la voz de una mujer afrodescendiente. Por ello, por medio del análisis de su Diario Espiritual, escrito entre 1650 y 1661, y publicado en Lima en el 2004, este artículo estudiará la identidad que construye Úrsula de Jesús en su texto, la cual reinterpreta el dogma católico imperante y construye una espiritualidad mistica negra.

Palabras clave: Úrsula de Jesús, misticismo, espiritualidad negra, donada, Diario Espiritual, escritura conventual

\section{ABSTRACT}

The present article studies the case of the black donada Ursula de Jesus (Lima, 1604-1666), whose exceptional religiosity was described by a Franciscan friar and nun, both anonymous. She spent the greater part of her life inside the convent of Santa Clara, which she entered as the slave of a nun of the black veil. Later she obtained her liberty and, supported by certain nuns, entered as a donada. She went on to write a Spiritual Diary in which she described her everyday life in the convent and the vicissitudes of her spirituality. While we know of other Afro-descendants who were recognized for their piety, we know them only through the dominant discourse that shaped their individual experiences to make them fit the models of Western sanctity. In this case, it is the opposite: the Spiritual Diary allows us to hear the voice of an Afro-descended woman. Through an analysis of the Spiritual Diary, written between 1650 and 1661 and published in Lima in 2004, this article studies the identity that Ursula de Jesus constructs in her text, which reinterprets the reigning Catholic dogma and constructs a Black mystical spirituality.

Keywords: Ursula de Jesus, mysticism, black spirituality, donadas, Spiritual Diary, convent writings 
G $\mathrm{n}$ el siglo XVII, Lima era uno de los centros físicos y simbólicos del poder colonial en Hispanoamérica y formaba parte de la efervescencia espiritual barroca de la Contrarreforma católica. La Ciudad de los Reyes congregaba a una variopinta población, compuesta por españoles, criollos, indios y, sobre todo, por una gran cantidad de africanos y afrodescendientes, esclavos y libres. En esta ciudad, los esclavos laboraban en diversos sectores urbanos, principalmente en actividades artesanales y comerciales, y las esclavas, mayoritariamente, en el ámbito doméstico y conventual. Un esclavo en Lima del siglo XVII no era ajeno a lo que acontecía en la ciudad; más bien, estaba envuelto por sus dinámicas, rodeado por sus magnificentes construcciones y abrumado por las expresiones cotidianas de los poderes político y religioso, como los autos sacramentales, los autos de fe, las procesiones y los sermones. En este sentido, los esclavos formaban parte integral de la urbe. Así, en el ámbito religioso, se les buscaba incorporar al catolicismo universal a través de distintos métodos, como el bautismo, la asistencia a misa, el matrimonio y la participación en cofradías, todo ello con la intención de controlarlos mejor.

Diversos autores coinciden en señalar que el tipo de esclavitud urbana que se desarrolló en Lima flexibilizó la situación de los esclavos, pues instituciones como el Estado y la Iglesia se superpusieron al poder absoluto que, en otros escenarios, tenía el amo. ${ }^{1}$ En este sentido, en Lima sucedía un fenómeno similar al que describe Herman Bennett para la Ciudad de México: los afrodescendientes no solo tenían el estatus de esclavo que los identificaba como bienes muebles, sino que, además, el pensamiento político de la época los identificó como vasallos del rey y como sujetos católicos. ${ }^{2}$ Como consecuencia, los esclavos estaban inmersos en una ciudad que les otorgaba ambiguas y diversas categorías que se sumaban a aquellas que ya equiparaban lo negro con lo abyecto, lo bárbaro, lo iletrado, lo inmoral e inclusive con el diablo. ${ }^{3}$ En este contexto, se dio

1 Hünefeldt 1988, Lévano 2002, Bennett 2003, Jouve-Martín 2005, Arrelucea 2010, McKinley 2012 y Graubart 2013.

2 Bennett 2003: 3-5.

3 «Esclava Úrsula, criolla de Panamá borracha, vil y de costumbres estragadas», 1618, 
un proceso de criollización mediante el cual los afrodescendientes se sumergieron en las "prácticas culturales de poder» y, a su vez, crearon nuevas identidades con las que genuinamente se identificaban. ${ }^{4}$ Dichas identidades sin duda surgieron como producto de la experiencia colonial — como esclavos, como vasallos y como católicos-, pero también ejercieron una influencia significativa en el sistema. ${ }^{5}$

En este sentido, el presente artículo tiene como principal objetivo analizar el caso de la donada negra Úrsula de Jesús (Lima, 1604-1666), quien, al interior del monasterio de Santa Clara de Lima, escribió un Diario Espiritual en el cual construyó su identidad como sujeto católico y edificó un modelo de santidad negra. El personaje en cuestión no es único por ser una afrodescendiente piadosa, pues también existieron otros como ella. Por ejemplo, el mulato Martín de Porres, el donado Francisco de la Concepción, la beata Estefanía de San Joseph y muchas otras donadas negras fueron reconocidos por sus virtudes y dones de profecía, de sanación y de caridad. ${ }^{6}$ Conocemos a estos personajes a través del discurso dominante, el cual los muestra como buenos cristianos que imitaron los modelos de santidad occidentales, como ejemplos de la eficacia de la evangelización en el Nuevo Mundo y como evidencia de la sacralización del territorio recientemente conquistado. ${ }^{7}$ Lo excepcional del caso de Úrsula de Jesús reside en que su Diario Espiritual permite oír la voz de una mujer afrodescendiente que construyó un modelo de santidad negra. En otras palabras, esta donada negra no es un ejemplo de alguien a quien la cristianización moldeó, sino de alguien que reinterpretó el dogma católico dominante. Con ello, este artículo propone que el Diario Espiritual encierra un discurso criollo que logra conciliar una identidad asignada, como la de sujeto católico, con una nueva: la de mística negra.

Archivo Arzobispal de Lima [en adelante AAL], Causas de Negros, leg. III, exp. 13; "Comportamientos impropios de esclava», 1627, AAL, Causas de Negros, leg. V, exp. 22; "Esclava con malas costumbres», 1630, AAL, Causas de Negros, leg. VI, exp. 6;

O’Toole 2012: 152; y Brewer-García 2013: 29.

${ }^{4}$ Graubart 2009: 473.

5 Bennett 2003: 7

6 Tardieu 1997, I: 878; Van Deusen 2012a: 50-52.

7 Rubial 2004: 127; Osorio 2008: 137; Brewer-García 2013: 262; y Cussen 2014: 9. 


\section{EL PERSONAJE}

Úrsula de Jesús nació en la Ciudad de los Reyes a inicios de un siglo caracterizado por la práctica de una extremada piedad religiosa entre sus habitantes. En aquel momento, una gran cantidad de hombres y mujeres tuvo una vida devota y ejemplar. Unos pocos, como Rosa de Santa María, fueron reconocidos como santos por el catolicismo romano, mientras que otros solo ganaron reconocimiento en el ámbito local y popular. Entre las mujeres, tanto laicas como religiosas, tuvo gran acogida la espiritualidad mística, la cual buscaba el conocimiento pleno de Dios a través del recogimiento interior y de su intervención sobrenatural y extraordinaria. Además, la experiencia mística suponía la creencia en milagros, alucinaciones, levitaciones y la interacción cotidiana con personajes como el diablo, los santos y las almas del purgatorio. ${ }^{8}$ En un contexto en el que imperaba una concepción negativa acerca de las mujeres — quienes eran vistas como propensas a desviarse de la ortodoxia y, por consiguiente, debían supeditarse a figuras masculinas, estar alejadas de las esferas de poder y permanecer en la «santa ignorancia»—, el misticismo les permitió resignificarse como sujetos femeninos a través de sus cuerpos, de la escritura y de la posición de poder que algunas lograron adquirir. ${ }^{9}$

Durante su «vida en el siglo», Úrsula de Jesús tuvo un particular acercamiento al movimiento místico femenino limeño, el cual le otorgó nuevos alcances espirituales que, eventualmente, le permitirían reconstruirse como sujeto católico. En un primer momento, vivió en casa de Gerónima de los Ríos (Sevilla, s/f-Lima, 1616?), en donde su madre trabajaba como esclava doméstica. ${ }^{10}$ Luego, en el año de 1612, fue a vivir con la mística Luisa de Melgarejo (Tunja, 1578-Lima, 1651), quien era considerada, en el ámbito popular, como una intercesora celestial y, por algunos miembros de la jerarquía eclesial y diversos hagiógrafos, como

8 Sánchez y Rodríguez 2000: 116-120; y Loreto y Lipsset-Rivera 2002: 187.

9 Arenal y Schlau 1990: 25-29; Mannarelli 1999: 21-22; Van Deusen 1999: 48, y 2007 : 23-24, 46; y Myers 2003: 14. El término «santa ignorancia» hace referencia al estado en el que debían permanecer las mujeres: sin leer y sin escribir, pues se creía que podían apropiarse de manera incorrecta del contenido de los libros.

${ }^{10}$ Van Deusen 2012a: 36-39. 
una mujer del más alto grado de perfección espiritual. ${ }^{11}$ Su casa era un microcosmos de la espiritualidad barroca de la época, desbordada de pinturas, esculturas y objetos religiosos y en donde, además, se reunían otras mujeres que, como ella, tenían arrebatos místicos y leían textos espirituales en voz alta. ${ }^{12}$ La pequeña Úrsula, durante sus años en esta casa, fue testigo ocular de todo lo que sucedía: participaba indirectamente de tertulias, aprendía hábitos y, sobre todo, presenciaba diversas manifestaciones y prácticas de la cultura mística femenina de la época:

en el convento de San Francisco le dijeron que estaba Luisa arrobada: estaba arrimada a la pared de la capilla mayor, tenía la cabeza arrimada a la pared y los ojos hacia arriba entre abiertos sin mover nada de su cuerpo en todo el tiempo que se dijo misa, al finalizar la misa entró una negrita y la llegó a hablar al oído, le dijo que quería que los huevos fuesen a estar pasados por agua y volvió la cabeza, luego se volvió a poner como estaba. ${ }^{13}$

Ciertamente, no podemos determinar si la «negrita» de la cita era Úrsula de Jesús; no obstante, dicho texto permite entrever cómo los esclavos formaban parte integral de las dinámicas y los eventos que transcurrían en La Ciudad de los Reyes y, en específico, de las prácticas espirituales del momento. Algunos afrodescendientes incluso participaron en las actividades espirituales de los conventos, espacios que, por excelencia, buscaban promover el desarrollo espiritual de su población, compuesta por aproximadamente el 10\% de los habitantes de la ciudad.

${ }^{11}$ Luisa de Melgarejo fue esposa de Juan de Soto, relator de la Real Audiencia y rector de la Universidad de San Marcos (Van Deusen 2012a: 36-39). Las autoridades religiosas del momento recurrieron a ella para que diera su testimonio en los procesos de beatificación de Rosa de Santa María y de Francisco Solano, lo cual refleja la importancia que tenía esta mujer en su época. De igual manera, Diego de Córdoba y Salinas, autor de la crónica de la orden franciscana, dedica un capítulo a la vida modélica de esta mujer (Córdova y Salinas 1957, V: 969; y Van Deusen 2012a: 40-41).

12 Testamento de Luisa de Melgarejo, 1651, AAL, Testamentos, leg. XXXI, exp. 5; Testimonio de Inés de Velasco, 1623, Archivo Histórico Nacional de Madrid [en adelante AHN], Inquisición, Proceso de fe de Luisa de Melgarejo, leg. 1647, exp. 5, f. 13r-v; y Testimonio de Isabel de Soto, 1623, AHN, Inquisición, Proceso de fe de Luisa de Melgarejo, leg. 1647, exp. 5, f. 20r-v.

13 Testimonio de Pedro Rodríguez de Toro, 1623, AHN, Inquisición, Proceso de fe de Luisa de Melgarejo, leg. 1647, exp. 5, f. 19. 
En el caso de los monasterios femeninos, las monjas dedicaban sus vidas a la contemplación y, cada hora del día, a una actividad que las ayudara a avanzar en el camino de la perfección, como la asistencia a misa, el rezo del rosario, la meditación y la lectura de libros espirituales, entre otras responsabilidades. ${ }^{14}$ Para las autoridades eclesiásticas, la reclusión femenina favorecía la vigilancia de las monjas, a las cuales se intentaba fiscalizar mediante visitas periódicas, reglamentos que regularan la vida interna y confesores que velaran por la práctica de una espiritualidad ortodoxa. Sin embargo, en muchos casos, los monasterios fueron espacios de empoderamiento y de autonomía femenina, ya que las monjas gozaron de libertad de acción lejos de las miradas vigilantes de figuras masculinas y subvirtieron muchas reglas que imperaban sobre las laicas. Así, por ejemplo, construyeron redes de poder que se extendieron al exterior del convento y transgredieron los mandatos de «santa ignorancia», pues leyeron y escribieron textos espirituales.

Parte de la población de los monasterios femeninos estaba compuesta por afrodescendientes, quienes vivían en la paradoja de ser sujetos católicos y no tener la posibilidad de dedicar por completo sus vidas a Dios. Uno de estos personajes fue Úrsula de Jesús, quien ingresó al monasterio de Santa Clara en 1617 como esclava de una monja de velo negro llamada Inés del Pulgar. Dentro se reproducían las jerarquías sociales de los extramuros, de tal manera que a todas las ingresantes se les asignaba una categoría en función de su calidad, poder económico, linaje y status social. Si bien algunas formaban parte del grupo más privilegiado de monjas de velo negro y otras, del no tan privilegiado grupo de monjas de velo blanco, la mayoría pertenecía a los grupos encargados de los trabajos más duros y mundanos del monasterio: las donadas, las esclavas y las sirvientas. Todas ellas se diferenciaban por el tipo y el color de hábito que vestían, por las funciones que les correspondían cumplir y por el poder de voto y de mando para decidir sobre el monasterio.

${ }^{14}$ Tabla de oficios de las religiosas, 1653, AAL, Monasterio de Santa Clara, leg. IX, exp. 70; Tabla de oficios de las religiosas, 1655, AAL, Monasterio de Santa Clara, leg. IX, exp. 134; y Tabla de oficios de las religiosas, 1656, AAL, Monasterio de Santa Clara, leg. IX, exp. 157. 
Como esclava, Úrsula de Jesús se ubicaba en la esfera más baja de esta jerarquía, por lo que debía servir a las monjas de velo negro y blanco y realizar diversas tareas domésticas, como preparar comidas, hornear el pan, lavar la ropa, limpiar las habitaciones, los espacios comunes, la enfermería y las acequias, entre otras. ${ }^{15}$

Naturalmente, el ingreso de Úrsula de Jesús al monasterio femenino le permitió presenciar aún más de cerca la espiritualidad barroca y, a su vez, reconocerse como esclava y repensarse como sujeto católico. Sus deberes mundanos se contradecían con el ambiente espiritual del monasterio, el cual custodiaba innumerables lienzos y esculturas barrocas que retrataban el sufrimiento de la pasión de Cristo y de los santos, apelaban a la emotividad de los espectadores y los invitaban a reflexionar. ${ }^{16}$ A pesar de ser esclava, Úrsula de Jesús era también uno de estos espectadores. Por ello, en muchos pasajes del Diario Espiritual, registra cómo era interpelada por este ambiente espiritual y su importancia al momento de meditar y de orar. Por ejemplo, en una ocasión, contó lo siguiente: «después cerca de la oración me puse delante de una imagen del descendimiento, que está en un claustro, y vi de allá, en una altura grandísima en un trono, las tres divinas personas». ${ }^{17}$ Dicha cita refleja el rol trascendental que cumplía el espacio monacal en el cultivo de su espiritualidad mística, no obstante, al mismo tiempo, en otros fragmentos del texto, se mostraba contrariada ante la paradoja en la que se encontraba. Por ejemplo, narra que a veces quería dedicar su noche a orar ante el Santísimo y, sin embargo, su cuerpo le impedía hacerlo, pues estaba agotado por haber estado trabajando todo el día en la comida del convento; a veces, asimismo, sentía "ansias de ir a donde está el señor», pero las monjas le pedían que preparara guisos y le quitaban el poco tiempo que le quedaba. ${ }^{18}$

${ }^{15}$ Fernández 1997: 444-454; Velázquez 2006: 179; Burns 2008: 164; y Van Deusen 2012a: 59.

${ }^{16}$ Cuentas del monasterio, 1626-1629, AAL, Monasterio de Santa Clara, leg. III, exp. 23; Visita general, Inventario de bienes, 1715, AAL, Monasterio de Santa Clara, leg. XXIV, exp. 18a; Fernández 1997: 129; Lavrín 2007: 153; Burns 2008: 138 y 164; y Van Deusen 2012b: 149.

${ }^{17}$ De Jesús 2012: 98

${ }^{18}$ Ib.: 31. 
El monasterio de Santa Clara, un lugar altamente jerarquizado y favorable para el empoderamiento y autonomía de las monjas de velo negro y blanco, también permitió e incluso impulsó la a veces heterodoxa espiritualidad mística de Úrsula de Jesús. Su admirable devoción llevó a que algunas monjas de velo negro la apoyaran económica y políticamente para comprar su libertad y, posteriormente, para que profesara como donada. Con ello, Úrsula de Jesús avanzó en la jerarquía conventual, consiguió ciertos privilegios y adoptó una nueva identidad. Como donada, se situó por encima de las esclavas, pudo residir permanentemente en el monasterio, apareció en la lista de tareas junto a las monjas de velo negro y blanco, profesó los mismos votos que ellas y se le encargaron oficios más importantes y vinculados con lo sagrado. ${ }^{19}$ Por ejemplo, Úrsula de Jesús debía ayudar en la cocina en fechas especiales, atender a las enfermas, encargarse de la limpieza de la enfermería y hacer de celadora en espacios como la capilla y el coro. Su labor en la enfermería le permitió aprender de los médicos y de las ensalmadoras - aquellas que curaban mediante el empleo de rezos y remedios - y su labor como celadora revela la confianza que la abadesa y la comunidad de monjas habían depositado en ella. Si bien no existe un documento oficial que permita corroborar que efectivamente tenía asignado este último oficio, su Diario Espiritual relata las veces que le hacía saber a la abadesa del mal comportamiento de las monjas clarisas. ${ }^{20}$

Como donada, además, se pudo aproximar a la cultura letrada y, eventualmente, escribir su Diario Espiritual. Durante el año de noviciado, previo a su profesión como donada, tuvo que leer la vida de los santos y memorizar las reglas del monasterio. ${ }^{21}$ Probablemente aprendió a leer a lo largo de ese tiempo, pero también es posible que alguna monja cercana, como la que compró su libertad, le enseñara a leer y a escribir, si no lo había hecho ya Luisa de Melgarejo. Inclusive, en algunas ocasiones, se refiere al hecho de que algunas monjas amigas le leían en voz alta. ${ }^{22}$ En el texto, Úrsula de Jesús le otorga un lugar especial a los libros, pues los

19 Tardieu 1997, I: 395; Burns 2008: 145; Van Deusen 2012a: 74, y 2012b: 136-148.

${ }^{20}$ De Jesús 2012: 15, 21, 29, 40, 73, 89, 127.

${ }^{21}$ Van Deusen 2012b: 141.

${ }^{22}$ De Jesús 2012: 88 y 110. 
consideraba herramientas útiles para avanzar en el camino de la perfección y para seguir los misterios de la vida y de la pasión de Cristo. Por ejemplo, uno de los pasajes del texto narra lo siguiente: «un día destos me dijeron a este propósito que si eran simples o ignorantes que por eso había sermones y consejos y libros». ${ }^{23}$

Leyó, por ejemplo, la Imitación de Cristo, del canónigo agustino Tomás de Kempis (1380-1471); Trabajos de Jesús, del fraile agustino Tomé de Jesús (1529-1582); y otros libros sobre las vidas de místicas hispanoamericanas y europeas. Por ejemplo, en algunos aspectos de su espiritualidad, destaca la influencia de Santa Gertrudis (1256-1302), Santa Brígida de Suecia (1303-1373) y Santa Catalina de Siena (13471380). Por ello, el franciscano anónimo que escribió su biografía narra que, tras recibir una bendición de Dios, Úrsula de Jesús le preguntó: «Señor mío, soy Yo Santa Catalina o Santa Gertrudes?». ${ }^{24}$ Pero, especialmente, Úrsula de Jesús siguió el ejemplo de Santa Teresa de Ávila (1515-1582), nombrada en diferentes partes del Diario Espiritual. Por ejemplo, en una ocasión, le dijo al Señor lo siguiente: «yo quisiera ser el poyto en que subía su majestad para subir en el pollino en que entró en Jerusalén, este día luego me respondió para que le recibiese humilde, reconocida y agradecida, que así lo hacía la santa Teresa de Jesús». ${ }^{25}$ En otra ocasión, contó: "tuvo esta hermana deseo de que le leyesen e[1] libro de Santa Teresa y desde entonces en algunas le dicen que su libro ha de ser los pies de mi señor Jesucristo». ${ }^{26}$ Teresa de Ávila registró sus experiencias espirituales, cuestionó la autoridad de sus confesores y de la jerarquía eclesial, y defendió la lectura de libros prohibidos. ${ }^{27}$ Por estos motivos, impactó grandemente en la escritura conventual y, además, en la construcción de la identidad católica de Úrsula de Jesús.

${ }^{23}$ Ib.: 61 y 88 .

${ }^{24}$ Van Deusen 2012a: 11

${ }^{25}$ De Jesús 2012: 180.

26 Ib.: 110.

${ }^{27}$ Myers 2003; Borges 2007; y Van Deusen 2007: 37 


\section{EL DIARIO ESPIRITUAL}

Según lo dicho, el acceso a las obras que produjeron estas místicas, así como las hagiografías y los sermones basados en sus vidas, hicieron a Úrsula de Jesús depositaria de una larga tradición de experiencias espirituales y de conocimiento de Dios producidas desde circunstancias particulares, pero que ella supo adaptar a las propias. En los monasterios femeninos, proliferó la escritura de autobiografías, cartas y diarios, todos ellos narraban las exploraciones de la religiosidad interior de las monjas — como visiones, éxtasis e interpretaciones teológicas de la experiencia personal y mística- y las descripciones de su vida activa, secular y familiar. Como consecuencia, estos textos contienen historias circulares y repetitivas que reflejan lo inalterable de la vida conventual; estaban siempre rodeadas de los mismos elementos y textos litúrgicos. ${ }^{28}$ Pero, sobre todo, la escritura mística conventual se caracterizó por ser desordenada y confusa, repleta de saltos en el tiempo, comentarios entre paréntesis, recuerdos y pensamientos intermitentes. Además, lo desbordante e inaprensible de la experiencia mística volvió aún más compleja la narrativa, debido a la imposibilidad del lenguaje de representar una experiencia netamente. ${ }^{29}$

El Diario Espiritual de Úrsula de Jesús reprodujo algunas convenciones de la escritura conventual, pero, la mayoría de las veces, las incumplió. De la misma manera que otras monjas, Úrsula registró su vida cotidiana al interior del monasterio, pero, además, incluía relatos vinculados exclusivamente a su posición en la jerarquía conventual. Por ejemplo, describe su día a día como donada, las labores que realizaba, las relaciones que tenía con las otras religiosas y los conflictos que existían al interior del monasterio. Asimismo, el texto contiene abundante información sobre las vicisitudes de su vida espiritual; así, narra sus rutinas de recogimiento, de oración y de meditación, y sus prácticas de penitencia y mortificación. También registra las innumerables visiones que la ponían en contacto con las almas del purgatorio y los coloquios que tenía con Dios, la Virgen

${ }^{28}$ Arenal y Schlau 1990: 27, 34-35.

${ }^{29}$ Van Deusen 1999: 52; y Certeau 2007: 352-354. 
María y su Ángel de la Guarda. La combinación imprecisa de los hechos de su vida terrenal y sus experiencias extrasensoriales añade un nivel de complejidad a la narración. ${ }^{30}$

Otro aspecto particular del Diario Espiritual es la aparente colaboración de más de una escritora. ${ }^{31}$ Ciertas referencias en el texto parecen sugerirlo; por ejemplo, en una ocasión se señala lo siguiente: «habíame pedido la que escribe esto que le hiciera una pregunta a Nuestro Señor acerca de una tentación». ${ }^{32}$ Como consecuencia, en el texto se evidencian cambios abruptos de la primera a la tercera persona y diferentes formas estilísticas. Así, en una parte del texto se hace referencia a Úrsula de Jesús en tercera persona: «ella dijo entre sí qué tienen estas monjas y respondele nuestro padre San Francisco si tomaran el libro de la regla y lo leyeran no estuvieran así o si pensaran en esto sacando una calavera ella estaba deseando prepararse para la comunión». ${ }^{33}$ Además, la narración mezcla la tradición oral y la tradición escrita; es decir, la voz de Úrsula de Jesús se funde con su puesta por escrito por la amanuense. ${ }^{34}$ Si bien es difícil comprobar si esta donada negra escribió por sí sola el Diario Espiritual o si lo hizo con ayuda de otras monjas, esta interrogante no resta autenticidad a la fuente. En un caso similar recogido por Rosalva Loreto para el virreinato de Nueva España, la monja Francisca de la Natividad fue encargada de escribir la vida de la monja Isabel de la Encarnación. ${ }^{35} \mathrm{La}$ biografía de Isabel se transformó en una autobiografía de Francisca, la amanuense, quien comenzó a existir a través de la primera. Considero que en el Diario Espiritual de Úrsula de Jesús no sucedió lo mismo. Por el contrario, el discurso construido en el texto solo puede ser entendido si se le reconoce como fruto de la experiencia colonial de una mujer afrodescendiente.

${ }^{30}$ Van Deusen 2012a: 156.

${ }^{31}$ Martínez i Álvarez 2004: 212; y Van Deusen 2012a: 149-160.

${ }^{32}$ De Jesús 2012: 93-94; el énfasis en esta y las siguientes citas ha sido agregado por la autora.

${ }^{33}$ Ib.: 69.

${ }^{34}$ Martínez i Álvarez 2004: 213; y Van Deusen 2012a: 156.

${ }^{35}$ Loreto 2002: 24-39. 
Por su contenido, el Diario Espiritual pareciera asemejarse a otros escritos conventuales; sin embargo, la mezcla de su negritud y su identidad católica produce un abigarrado escrito místico. Un claro ejemplo de cómo coexisten las convenciones y las transgresiones del género literario se encuentra en la narración de su experiencia de conversión. Este relato hace gala de un manejo exquisito de las prácticas culturales de la sociedad limeña, de lo que aprendió en casa de Luisa de Melgarejo y de las nuevas dinámicas del monasterio. Tras casi morir al caer a un pozo y ser salvada de milagro, Úrsula de Jesús dejó de «engalanarse y contornearse» y transformó su vida al servicio de Dios, pues interpreta esta experiencia límite como una advertencia divina para que dejase de vivir en pecado: «quedó Úrsula tan agradecida a Dios y a su madre sacratísima por este señalado beneficio, que al punto vendió todas sus galas y vestidos e hizo un gran propósito de servir muy de veras al altísimo y de darse mucho a la oración y trato interior con su majestad divina». ${ }^{36}$

Ciertamente, su conversión se asemeja a las muchas otras que se narraban en las biografías y autobiografías de personas virtuosas, pues era un lugar común que una señal o experiencia con la muerte se considerara el hito de inicio de sus vidas piadosas. ${ }^{37}$ No obstante, al mismo tiempo, refleja el lugar paradójico de Úrsula de Jesús al interior del monasterio, pues su encuentro con la muerte acontece cuando estaba realizando sus labores de esclava. Pero, sobre todo, su conversión tiene un significado adicional, pues hace referencia a la adopción de una nueva identidad, aquella que ella misma se atribuye. Más allá del estatus de esclava con el que era nombrada en los documentos del monasterio que certificaron su ingreso al mismo o en las listas de distribución de los oficios, ella se construye como una mujer negra y mística.

${ }^{36}$ Anónimo 2012b: 7-9; y De Jesús 2012: 26. Un hecho similar ocurrió con un fraile franciscano quien murió a vísperas de unas elecciones, pues «si llegara a votar, se había de condenar porque estas elecciones engendran la mala voluntad, que es el gusano que carcome las almas hasta dar con ellas en el infierno, más que la santísima trinidad de quien era muy devoto le hizo la caridad de librarle de este peligro quitándole la vida» (De Jesús 2012: 63).

${ }^{37}$ Van Deusen 2012a: 18-20. 
En el Diario Espiritual, confluyen ciertas figuras retóricas de la escritura conventual, como el empleo de fórmulas de debilidad que trasforma a partir de la manera distinta en que concebía su feminidad, su cuerpo y su ubicación en las jerarquías sociales y conventuales. En los textos místicos convencionales, las monjas escribían en un lenguaje aceptado por la autoridad para maquillar el tono subversivo de su discurso. Como consecuencia, mostraban sumisión ante las reglas de silencio y de la «santa ignorancia», evadían la responsabilidad de lo que escribían, negaban tener voluntad y agencia, se representaban absolutamente obedientes y abnegadas, y se autodespreciaban. ${ }^{38}$ En el caso del Diario Espiritual, estas fórmulas retóricas le permitieron expresar, discutir y rebatir las connotaciones negativas que recaían sobre ella como consecuencia de las distintas identidades y calificaciones que el sistema colonial y la población le habían otorgado. En este sentido, su nueva identidad de mística negra es construida a partir de su reconocimiento como afrodescendiente y de su experiencia colonial, y no a pesar de ella. ${ }^{39}$

En las descripciones acerca de su espiritualidad interior, Úrsula de Jesús señalaba no tener voluntad ni agencia ni control sobre sus experiencias con la esfera celestial. Es decir, al momento de relatar sus coloquios con Dios, la Virgen María y las almas del purgatorio, enfatizaba que no los había deseado y que tampoco tenía control sobre las palabras que salían de su boca. Por ejemplo, en una ocasión señalaba lo siguiente: "yo cuando hago estas preguntas no las hago porque quiero, sino que así como veo y me hablan sin que quiera, asi me hacen hablar sin quererlo yo». ${ }^{40}$ Es decir, Úrsula de Jesús no asumía ninguna responsabilidad sobre sus acciones. Incluso a pesar de oponer resistencia, seguía teniendo visiones y era incapaz de controlar su cuerpo, sus palabras y sus sentidos. No obstante, a la resistencia solía seguirle una resignación favorable, pues sugiere que Dios la gobernaba y la controlaba. De esta forma, en relación a una visión que tuvo de la pasión de Cristo, señalaba

\footnotetext{
${ }^{38}$ Arenal y Schlau, 1990: 25.

${ }^{39}$ Brewer-García 2013: 268.

${ }^{40}$ De Jesús 2012: 5.
} 
lo siguiente: «Dios que quiere que siempre vea lo que hizo y padeció con nosotros [...] aunque yo más hiciera no podía hacer ni inventar aquello que pasa acá dentro que no es mío más que solo cuando Dios quiere». ${ }^{41}$ Como consecuencia de la responsabilidad divina de sus acciones, Úrsula de Jesús legitimaba su discurso, pues su yo afrodescendiente —inferior, incivilizado, propenso a los engańos del demonio - era reemplazado por un yo divino y masculino. ${ }^{42}$

Otro personaje que aparece constantemente en la narración es el diablo, a quien también se le atribuye parte de la responsabilidad sobre la vida espiritual de Úrsula de Jesús. Este singular personaje es llamado de diferentes maneras en el texto — embustero, patón, enemigo, malignoy es representado con distintas figuras, como la de un dragón o la de un perro. Ciertamente, sus apariciones evidencian su relevancia en el imaginario de la época como un ser que buscaba hacer caer en la tentación a las personas. En ese sentido, pasajes como el siguiente se repiten asiduamente en el texto:

Sábado después de pascua, no sé qué es esto, no sé si son embustes del enemigo Dios lo sabe y sea conmigo que no sé cómo librarme de estas cosas, entrando hoy en la siesta a los confesionarios en llegando al arco donde estaba la iglesia o la reja me dio un grandísimo pavor más fiada de Dios lo vencí y pasé adelante y luego que me puse en los pies del señor recogida me pareció que sentía pasar por donde yo estaba hacia la reja que solía ser y con el espíritu quise huir de allí y fue imposible. ${ }^{43}$

La presencia del demonio en el texto y en su vida espiritual podría parecer perjudicial, pues confirmaba la idea que primaba en la época de que los negros, como resultado de su barbarismo, dependían y eran persuadidos por él. De hecho, se usaban los términos «negro» $\mathrm{y}$ "demonio» como sinónimos, pues se creía que la oscuridad reflejaba la ausencia y desconocimiento de Dios. ${ }^{44}$ Sin embargo, el lugar que ocupa este personaje en la narración no es casual; por el contrario, Úrsula de Jesús lo incorpora

41 Ib.: 119.

${ }^{42}$ Van Deusen 2007: 48.

43 Anónimo 2012a: 27.

${ }^{44}$ O’Toole 2012: 137; y Brewer-García 2013: 29, 62. 
conscientemente para discutir con las nociones erróneas que imperaban sobre sí misma y el resto de afrodescendientes.

De esta manera, a pesar de aparecer en sus visiones, el diablo no invalidaba su espiritualidad mística, sino que la legitimaba, pues Úrsula de Jesús compartía la idea de que las tentaciones del demonio eran obras exclusivas de Dios, a través de las cuales ayudaba a perfeccionar el alma de aquellos que se unirían místicamente con él. Por ello, diversos pasajes del texto expresan que el diablo era un engańoso agente de la voluntad divina: «Disenme, ¿Que por qué tengo tanto miedo de aquel patón? Dije que porque era amigo de engańas. Dicen que si no era Dios más que millones de ellos. Y que si ellos tenian alguno poder, que si engaña o tienta, es porque Dios quiere. Y que por todo de gracias a Dios». ${ }^{45}$ Según lo dicho, es evidente que la espiritualidad mística de Úrsula de Jesús fue influenciada por las diferentes nociones que circulaban alrededor de los negros, ya que en el Diario Espiritual son traídas a colación y discutidas. Como en este caso, esta negra piadosa cuestiona el vínculo entre los negros y los demonios y, sobre todo, remarca su exquisito conocimiento de Dios y da cuenta de las bondades que él realizaba en su vida aun siendo una negra.

Otra de las estrategias retóricas que Úrsula de Jesús empleó a su conveniencia fueron las fórmulas de autodesprecio. La mayoría de las veces que habla con Dios o con las almas del purgatorio, les contesta que es en vano que recurran a ella porque es una "pecadora", una "nada", un "gusano" y que no merecía más que el infierno. ${ }^{46}$ ¿Acaso fue llamada así por las monjas del monasterio de Santa Clara o por su ama Inés del Pulgar? Probablemente sí. Su biógrafo, un franciscano anónimo, relata que tales eran los «disgustos y sinsabores» que le ocasionaba su ama que contempló la posibilidad huir del monasterio. ${ }^{47} \mathrm{Al}$ autodespreciarse, Úrsula de Jesús mostraba aceptar las nociones negativas que imperaban sobre los afrodescendientes, pues se declaraba inferior, pecadora y escasa

\footnotetext{
${ }^{45}$ Loreto y Lipsset-Rivera 2002: 186-187; y De Jesús 2012: 13-14.

${ }^{46}$ De Jesús 2012: 12, 30-31, 34, 118.

${ }^{47}$ Anónimo 2012b: 7.
} 
de aptitud intelectual. Sin embargo, esta estrategia retórica le permite reafirmar la autoridad de Dios sobre el Diario Espiritual y, por consiguiente, evidenciar que en ella solo recaía la labor de reescribir «el libro vivo» que Dios escribía sobre su cuerpo. En este aspecto, es evidente la influencia de Teresa de Ávila, pues ella también decía que las palabras que escribía eran de Dios; y ambas textualizaron las enseñanzas que Dios imprimía en sus cuerpos. ${ }^{48}$

Asimismo, esta fórmula de autodesprecio le posibilita cuestionar aquello que vinculaba lo negro con lo incivilizado y lo bárbaro. Por ejemplo, humanistas como Gerónimo de Pallas y José de Acosta consideraban que el uso del lenguaje y de la escritura garantizaba la adquisición de virtudes morales y de un comportamiento civilizado, pero, en el caso de los negros, se requería adicionalmente de disciplina física debido a la corrupción en la que se encontraban sus cuerpos. ${ }^{49}$ Úrsula de Jesús se desligó de esta concepción negativa, pues al escribir su Diario Espiritual expresó su civilidad y ferviente catolicismo y, al sugerir a Dios como autor, se ensalzó y anuló todo cuestionamiento posible, pues incluso siendo negra se representó como vehículo de la voluntad divina.

Además del uso de estrategias retóricas de debilidad, Úrsula de Jesús empleó fórmulas de fuerza en su narración. En la escritura conventual, las místicas incurrieron en temas que usualmente estaban restringidos para ellas. Por ejemplo, en sus textos, interpretaron los dogmas católicos de la Santísima Trinidad y de la Inmaculada Concepción de María, cuestionaron a las autoridades eclesiales y a las dinámicas conventuales, y se sugirieron como autoridades espirituales e intercesoras. ${ }^{50}$ En el caso particular del Diario Espiritual, Úrsula de Jesús se sugiere como modelo de servicio a Dios y como autoridad intercesora, critica la espiritualidad de las monjas del monasterio de Santa Clara y, sobre todo, construye una nueva identidad como mística negra. En este sentido, a pesar de las similitudes que en alguna medida comparte con la escritura femenina de

${ }^{48}$ Van Deusen 2007: 37-38, 48; y De Jesús 2012: 84.

${ }^{49}$ Brewer-García 2013: 56, 62.

${ }^{50}$ Arenal y Schlau 1990:. 25-28; y Van Deusen 2007: 49. 
la temprana Edad Moderna, Úrsula de Jesús crea un lenguaje propio que satisface su necesidad de enlazar y armonizar su negritud, su búsqueda de perfección y unión con Cristo y sus ansias de tener un lugar en el cielo. ${ }^{51}$

El Diario Espiritual recoge pasajes sobre las almas y las personas que consideraban a Úrsula de Jesús una autoridad intercesora; dichos dotes formaban parte integral de su nueva identidad. En el texto, se narran las innumerables peticiones que le hacían las almas del purgatorio para que intercediera por ellas ante Dios. A Úrsula de Jesús se le aparecían las almas de todos los sectores de la sociedad, entre ellas las de un fraile franciscano, una india donada llamada Sisilia, el antiguo sacristán del convento, un obrero de la Iglesia y el padre Miguel Rodríguez. ${ }^{52}$ Además de verlas, estas almas le describían sus penas: el licenciado Colonia, por ejemplo, le contó que padecía grandes trabajos por haber maltratado a su esclava Francisca, mientras que una monja clarisa le dijo que estaba por más de seis años purgando su alma por haber faltado en vida a las reglas de la religión. Pero fueron, sobre todo, las almas de origen afrodescendiente - como las de las esclavas negras María Bran y Luisa — las que ocuparon un lugar importante en su narración, y cuyas peticiones atendía con mayor esmero. ${ }^{53}$

No se debe olvidar que, en una época en la que existía una gran preocupación por la vida después de la muerte y el purgatorio era un tópico recurrente, los fieles católicos buscaban otras alternativas para saciar la incertidumbre de la salvación. Muchos recurrieron a la protección de los santos y de las intercesoras terrenales, como a las curanderas, a las beatas, a las monjas y, en este caso, a la donada Úrsula de Jesús. ${ }^{54}$ La importancia que les otorgaba Úrsula de Jesús a los santos, la cual seguramente era compartida por los limeños de la época, era mucha: «de cuanta impor-

${ }^{51}$ Graubart 2009: 473.

${ }^{52}$ De Jesús 2012: 3, 23, 47, 38. Nancy van Deusen da cuenta que dentro de las intercesiones por los muertos, las almas de origen afrodescendiente ocupaban un lugar especial; Úrsula de Jesús dota de nombre a las sirvientas y a las esclavas y atiende sus pedidos, lo cual evidencia su preocupación por su familia extensa afroperuana (2012a: 145-146).

${ }^{53}$ De Jesús 2012: 47, 56; y Van Deusen 2012a: 145-146.

${ }^{54}$ Van Deusen 2012a: 88, 119. 
tancia es tener santos por devotos y cuan solos se hallan los que pasan allá [en el purgatorio] sin ellos, trajo una comparación que si acá un hombre hiciese a un rey un presente de un millón todo cuanto le pidiese este hombre se lo concedería que así los santos alcanzan de Dios lo que le piden». ${ }^{55}$ Por ello, las personas de distintas calidades que reconocieron sus dotes intercesores acudían a ella para hacerle diversas peticiones. Así, una religiosa le pidió con mucho encarecimiento que encomendase a una amiga suya que estaba muy enferma; y otra la mandó a llamar para que pidiese por su madre que se estaba muriendo. ${ }^{56}$

Al narrar estos eventos reflejaba que vivos y muertos reconocían en ella a una negra que había alcanzado un alto grado de perfección espiritual y que, por lo tanto, se encontraba más cercana a Dios para transmitirle las peticiones del resto. En este sentido, la nueva identidad que construye Úrsula de Jesús la sugiere como una autoridad intercesora, capaz de injerir en la esfera celestial para reducir las penas de las almas del purgatorio y para sanar a personas que tenían una enfermedad incurable. Por ejemplo, en una ocasión ayudó a aminorar el sufrimiento de cuatro almas del purgatorio, las cuales volvieron a aparecérsele para expresarle su gratitud. ${ }^{57}$ Otro ejemplo de su poder intercesor se puede observar cuando cierto día salvó a una monja que se encontraba al borde de la muerte al hacerle cruces en nombre de la Santísima Trinidad; o cuando sanó y dejó sin cicatrices a una compañera clarisa que se había quemado: logró que la quemadura no levantara ampollas solo con echarle agua. ${ }^{58}$ Lo mismo sucedió con una negra enferma a quien salvó:

estando una negra para morir en este mes de marzo, fui a verla y le hice hacer un acto de contrición y solo mui de veras con muchas lágrimas y dándose muchos golpes en los pechos yo fui consolada de haberla visto a encomendarla a Dios y vi un santo Cristo y a sus pies a esta morena amortajada con

\footnotetext{
${ }^{55}$ De Jesús 2012: 56.

${ }^{56}$ Ib.: $14,18$.

${ }^{57}$ Ib.: 102. También narra la ocasión en que una monja se sentó en la enfermería y la comenzó a aplaudir, probablemente como muestra de afecto o consideración especial por los favores prestados (De Jesús 2012: 52).

${ }^{58}$ Ib.: 32, 103-104.
} 
que viera cierta su muerte y que por la misericordia de Dios se había de salvar y le di muchas gracias. ${ }^{59}$

Estos dos últimos ejemplos sugieren que, además de tener dotes intercesores, poseía dotes curativos. Probablemente, este aspecto de su nueva identidad surge a partir de su experiencia de trabajo en la enfermería del monasterio, donde tuvo la oportunidad de aprender técnicas curativas que, eventualmente, le permitieron ganarse una reputación como sanadora. A esto le adicionó los atributos de poder sanar a través del uso de remedios espirituales, como las oraciones, las señales de cruz y el agua bendita ${ }^{60}$ ¿Acaso insinuaba que tenía el don de hacer milagros? Posiblemente sí; a pesar de solo resolver obvias necesidades humanas, en aquella época se consideraba un poder sobrenatural. En este aspecto, la identidad que construyó calzó, en cierta medida, con el arquetipo de santo que primaba en el ámbito popular: evidencia de poder sobrenatural en vida, actos de caridad y buenas obras. ${ }^{61}$ Indudablemente, el Diario Espiritual es utilizado para dejar memoria de los muchos méritos que había realizado en vida — como su presto y eficaz auxilio de los enfermos y de las almas del purgatorio- con el objetivo de asegurarse un lugar en el cielo al morir.

Todas las visiones que narra, sugieren que Dios le había concedido la cualidad de la omnipresencia, pues Úrsula de Jesús decía tener la capacidad de vivir en la tierra y, al mismo tiempo, visitar y conocer lo que sucedía en el purgatorio. Como consecuencia, se enteraba de las grandísimas penas que padecían las almas para purificarse y los motivos que les habían impedido ir directamente al cielo. Ciertamente, como ya se ha mencionado, la nueva identidad que construyó se basó en su poder intercesor, pero también en su basta sabiduría. Úrsula de Jesús era una negra que decía conocer, más que cualquier otra religiosa clarisa, lo que le deparaba al hombre después de la muerte. Por consiguiente, los relatos sobre sus visiones tienen un fin didáctico, pues, de manera similar a las

\author{
${ }^{59}$ Ib.: 35 . \\ ${ }^{60}$ Ib.: 32, 35, 76, 103-104. \\ ${ }^{61}$ Weinstein y Bell 1982: 142-143, 159.
}


imágenes y esculturas barrocas que decoraban el monasterio, buscaban conmover al lector y lograr su conversión. ${ }^{62}$ Un ejemplo de ello se puede apreciar en la siguiente cita:

tendida de espaldas en una como barbacoa y alrededor muchísimos demonios y todos atormentándola de la boca y ojos oídos le salía un fuego como cuando pegan fuego a un cohete volador y no le dejan bolar con aquel ruido en la cabeza estaban tocándosela con mil géneros de tormentos los pies llegaban otros y se los calzaban con terribles yerros. ${ }^{63}$

Este retrato realista sobre el sufrimiento de las almas del purgatorio y las atrocidades de sus penitencias evidencia la intencionalidad de Úrsula de Jesús de enseñar el camino correcto y persuadir a sus potenciales lectores de pecar.

Su sabiduría y sus dotes intercesores también la dotaron de la autoridad y de las herramientas necesarias para criticar la vida de pecado que llevaban muchas religiosas del monasterio de Santa Clara y para exhortarlas a optar por el camino del bien. En su Diario Espiritual, Úrsula de Jesús deja constancia del estado de decadencia en el que se encontraba el monasterio de Santa Clara, al cual se refiere como el lugar donde más se ofendía a Dios. ${ }^{64}$ Allí, la mayoría de las monjas no respetaban sus votos, no cumplían con la regla del monasterio, no se encontraban por completo al servicio de Dios y no se preparaban para recibir la comunión ni se dedicaban a la oración. ${ }^{65}$ Por el contrario, se dedicaban a cuestiones mundanas, se la pasaban hablando horas de horas entre ellas y riendo en

${ }^{62}$ Rubial 2004: 140; y Van Deusen 2012a: 41.

${ }^{63}$ De Jesús 2012: 11-12.

${ }^{64}$ Ib.: 6.

${ }^{65}$ Cuentas del monasterio, 1626-1629, AAL, Monasterio de Santa Clara, leg. III, exp. 23; Provisor y vicario general para que cierren las puertas de los libratorios y no se permita que las monjas conversen negociando votos, 1635, AAL, Monasterio de Santa Clara, leg. V, exp. 18; Visita general, inventario de bienes, 1715, AAL, Monasterio de Santa Clara, leg. XXIV, exp. 18a; Papeles importantes, Cuaderno de autos tocantes a los monasterios de monjas, 1630, AAL, Monasterio de Santa Clara, leg. XXIV, exp. 8; Autos arzobispales relacionados con los monasterios de clausura, 1637, AAL, Monasterio de Santa Clara, leg. XXIV, exp. 10; Acerca de las visitas que reciben las monjas de clausura, 1685, AAL, Monasterio de Santa Clara, leg. XXIV, exp. 19; y De Jesús 2012: 6, 60, 67 y 69. 
el coro, faltaban al voto del silencio, estaban pendientes de la elección de la abadesa, formaban bandos entre ellas y profanaban su hábito al agregarle banalidades. ${ }^{66}$ Frente al mal comportamiento, Úrsula de Jesús buscaba remediar la situación dentro de sus posibilidades. Intercedía ante Dios por las almas de las religiosas clarisas que ya habían muerto y pedía por la conversión de aquellas que llevaban una vida de pecado. Así, le rogaba a Dios: "que tuviese misericordia desta casa y les diese su paz» y «muy encarecidamente que perdonase a los pecadores y particularmente a las monjas». ${ }^{67}$ Asimismo, buscó instruirlas en las enseñanzas que Dios depositaba en ella, para ayudarlas a que reorientaran sus vidas al camino correcto y alcanzaran la salvación de sus almas. Sin embargo, sus consejos no eran siempre bien recibidos; de hecho, en una ocasión, una monja amiga le recomendó «que no lo anduviera diciendo a todas que entraban en hondo y que era menester tratarlo con quien lo entendiera». ${ }^{68}$ Puede que este último comentario se haya referido a la divulgación de historias como la del alma de una religiosa clarisa que estaba por más de siete años en el purgatorio por haber faltado a las obligaciones de la religión:

estar en el coro con parlas y risas y faltando a las venias y a las demás ceremonias y el traje no conforme a la regla y tañer a silencio y no guardarlo y después de haber pasado la visita volverse a levantar y andar discurriendo de unas partes en otras hablando, murmurando, quebrantando silencio de las risas banas y el amor desordenado a las criaturas. ${ }^{69}$

${ }^{66}$ De Jesús 2012: 40, 51, 56, 63, 94.

${ }^{67}$ Ib.: 51, 60, 63, 68, 73 .

${ }^{68}$ Ib.: 34 .

${ }^{69}$ Ib.: 56. Otro ejemplo de las faltas que habían cometido las monjas que estaban en el purgatorio es el siguiente: «disenme desta que había ofendido a Dios porque había dado mal ejemplo en la comunidad, estaba en el coro un día que había procesión por la tarde y disenme que mirara yo si había visto yo otra vez aquello que estaba allí, volví a mirar y estaban hablando allí unas monjas que nunca las veo allí, otra vez estaba la monja que velaba aquel día al santísimo sacramento hablando con otras y disenme que si no fuera mejor estar pensando que no parlando, que más se ofendía a Dios con aquello que se servía» (De Jesús 2012: 51). 
Inclusive, le hizo llegar a la abadesa su preocupación por el estado de las monjas y le propuso elaborar cédulas que las exhortaran a prepararse antes de recibir la comunión. ${ }^{70}$ Sin embargo, a pesar del gran interés que muestra por la salvación de las clarisas, también se entrevé un sentimiento de justicia divina, pues en su discurso enfatiza que aquellos que habían maltratado a sus esclavos en vida eran los que primaban y sufrían más en el purgatorio. ${ }^{71}$

Su discurso acerca de las monjas clarisas era un cuestionamiento directo a las religiosas, a las antiguas superioras, a la jerarquía conventual y, en última instancia, al poder colonial. Los roles se habían invertido: ya no eran la Iglesia, el Santo Oficio, el Monasterio o su ama, representantes del poder absolutista, los que evangelizaban a una afrodescendiente y velaban por que no practicara la hechicería; ahora era una negra la que había asumido estos roles, y evangelizaba y vigilaba la espiritualidad de sus dominadoras clarisas. ${ }^{72}$ Por consiguiente, la voz que habla en el Diario Espiritual no es la de una donada, es la de una mística negra que había sido autorizada por Dios para escribir y leer, para conversar con las almas del purgatorio, para tener dotes intercesores y curativos, y, sobretodo, para unirse místicamente con él. Es decir, su nueva identidad le permite hablar desde una posición de superioridad moral: «con la autoridad de quien vio para quien no vio». ${ }^{73}$ Por tal motivo, su texto está lleno de contrastes entre las vidas de las religiosas y su propia vida. Mientras que aquellas eran pecadoras y no cumplían con las normas mínimas para servir a Dios, Úrsula de Jesús destacó que ella sí cumplía fehacientemente con la regla del convento y el silencio, con prepararse antes y después de recibir la comunión, con vestir los trajes permitidos, con realizar diariamente una rutina espiritual sumamente exigente, con no ser ociosa y con ser eficaz en sus labores espirituales y terrenales.

\footnotetext{
${ }^{70}$ Como parte de las fórmula de debilidad que empleó en su narración, Úrsula de Jesús señaló que este encargo se lo encomendó Dios; probablemente, de esta manera, podía cuestionar a las monjas sutilmente y tener más autoridad (De Jesús 2012: 73-74).

71 Brewer-García 2013: 297-299.

${ }^{72}$ Van Deusen 2012a: 143.

${ }^{73}$ Mezan 2007: 141.
} 
Y, sobre todo, al reconocerse como dueña de una moralidad superior y como una negra en la que Dios derramaba sus bendiciones, se permite discutir e interpretar teológicamente la posición de los afrodescendientes en el monasterio, en la sociedad y en el cielo.

Como ya se ha señalado, la espiritualidad mística de Úrsula de Jesús fue construida a partir de su negritud y no a pesar de ella; esto se puede observar, por ejemplo, en su concepción sobre su cuerpo negro, la cual discute con el pensamiento de la época que lo consideraba un cuerpo salvaje e incivilizado, incapaz de aprender las virtudes morales y cristianas a menos que se le disciplinara físicamente. ${ }^{74}$ En este sentido, su experiencia colonial la vuelve consciente de las ideas negativas que imperaban sobre los negros, sobre todo cuando existía justificación al maltrato que le infligía su ama clarisa; además, suscita en ella una nueva experiencia, en donde su cuerpo es resignificado positivamente al optar por la vía purgativa. ${ }^{75}$ De esta manera, el Diario Espiritual resalta los diversos modos en los que Úrsula de Jesús torturaba su cuerpo: lo sometía a constantes ayunos, pasaba las noches de rodillas en oración, colocaba coronas de espinas sobre su cabeza, apretadores con puntas de hierro en su cintura y cruces de púas en su espalda. ${ }^{76}$ Ello muestra que su concepción sobre su cuerpo difiere notablemente de la que se tenía sobre el cuerpo femenino. Su cuerpo no era frágil; por el contrario, era fuerte y recio, capaz de soportar todas estas mortificaciones y, además, sus labores como esclava. ${ }^{77}$

Para Úrsula de Jesús, estas penitencias eran equiparables al sufrimiento de Cristo; es decir, su cuerpo le concedía experimentar la imitatio christi. ${ }^{78}$

\footnotetext{
${ }^{74}$ Brewer-García 2013: 56, 62.

${ }^{75}$ Bennett 2003: 5. Tal era el maltrato que incluso contempló la posibilidad de huir del convento al verse «desconsolada» por los «disgustos y sinsabores» que tenía con su ama (Van Deusen 2012a: 7). Por otro lado, existían tres vías para llegar a la perfección: la purgativa (abandono del pecado), la iluminativa (cultivo de las virtudes), la unitiva (unión con Dios) (Borja 2009: 91).

${ }^{76}$ Van Deusen 2012a: 9; y De Jesús 2012: 43, 116.

77 Van Deusen 2012a: 52, 136-137.

78 Bynum 1987: 26; Arenal y Schlau 1990: 29; Fernández 1997: 129; Lavrín 2007: 157; Borja 2009: 90-93; y Van Deusen 2012a: 129, 135. La imitación de Cristo consistía
} 
En este sentido, además de todos los méritos que logró a través de la expiación — como purificar su cuerpo del pecado, perfeccionar su alma para el encuentro místico con Dios y reducir las penas de los desdichados del purgatorio- - ella sugiere que podía aliviar el sufrimiento de Cristo. Por ello, el Diario Espiritual contiene innumerables pasajes de los cuarenta días que pasó Jesús en el desierto en ayuno y sin descanso, de las siete caídas con la cruz a cuestas, entre otros fragmentos de su pasión que compara con su propio sufrimiento como negra. ${ }^{79}$ En ese sentido, el ofrecimiento de su cuerpo y de su trabajo a Dios era justificado, porque de esa manera recompensaba a Jesús por morir por la humanidad:

disenme que mire yo aquel señor que tanto había padecido en este tiempo por nosotros, yo decía: creo en Dios padre... así hace que le veía yo con las manos atadas angustiadísimo con sudores. Desianme que considerara yo que sentiría aquel señor por haberse encargado de todos los pecados del mundo. Decía yo que los míos bastaban para tenerle, así empeceme a afligir muchísimo tuviera mucha confianza que quien le deseaba agradar y amar e iba a sus pies no tenía que temer engańos del demonio. ${ }^{80}$

De lo anterior se deduce que, para Úrsula de Jesús, sus labores al interior del monasterio eran equiparables al sufrimiento de la pasión de Cristo. Tanto es así que, en una de sus visiones, observó a la Virgen María haciendo las camas de las monjas, con lo cual sugiere que la Virgen consideraba loables los quehaceres mundanos de una negra donada. ${ }^{81}$ Y, en otra ocasión, cuando se quejaba por la cantidad de trabajo que tenía en el convento, contó que Jesús le habló y le dijo que a él lo habían puesto en un palo como si fuera «un vil esclavo y ladrón»; como consecuencia dejó de lamentarse. ${ }^{82}$ Úrsula de Jesús reflexionaba

en imitar su sufrimiento, pero también en perseguir sus virtudes. Para Úrsula de Jesús, "quien no imitaba a nuestro señor Jesucristo en algunas de sus virtudes, no podía ser su hijo ni su discípulo: su humildad, su mansedumbre, su paciencia, su obediencia, su pobreza» (De Jesús 2012: 42).

${ }^{79}$ De Jesús 2012: 14, 88, 94.

${ }^{80}$ Ib.: 20.

${ }^{81}$ Ib.: 88; y Van Deusen 2012a: 138-139.

${ }^{82}$ De Jesús 2012: 31 
sobre sus agotadores deberes, pero se reconfortaba al caer en la cuenta que eran comparables a las del hijo de Dios: «que el cuerpo trabajara, él siempre trabajó, que cuando yo estuviera trabajando en pie pensara cuando lo tenían en pie, cuando padeció; que cuando trabajara sentada pensara cuando los sentaron en aquel banquito, yo no sé qué es esto, Dios lo sabe». ${ }^{83}$ Pero, además, al igual que la penitencia y el trabajo, vio en la eucaristía una oportunidad para aunarse a la agonía de Jesús, pues a través de ella su cuerpo negro podía alimentarse del cuerpo flagelado de Cristo. ${ }^{84}$ Probablemente fue por este motivo que Úrsula de Jesús valoró en sobre manera el sacramento eucarístico y todas las veces se preparaba con dedicación para recibirlo: consideraba que, al comer el cuerpo de Cristo, «se movía hacia Dios, no solamente al abandonar su físico deficiente sino también al convertirse en el sufrimiento y en el alimento de la humanidad». ${ }^{85}$

Su nueva identidad revalorizó y exaltó su cuerpo negro, pues de su discurso se deduce que solo aquellos que lo poseían eran capaces de progresar cabalmente en la vía purgativa y perfeccionar su alma para el encuentro con Dios. La fortaleza de su cuerpo lo hacía ver como un instrumento divino, porque, además de soportar mortificaciones voluntarias, soportaba agotadoras labores en la enfermería y en la cocina, tareas que se prolongaban a lo largo del día y hasta altas horas de la noche. Tantos eran los quehaceres que debía realizar que, en algunas ocasiones, no podía cumplir con sus rutinas diarias de recogimiento y oración, porque terminaba muy cansada o porque no le alcanzaban las horas del día para hacerlas. ${ }^{86}$ Además de sus obligaciones, su biógrafa clarisa escribió que realizaba tareas aún más inhumanas: «Era muy continuo

\footnotetext{
83 Ib.: 127.

${ }^{84}$ Bynum 1987: 3.

${ }^{85}$ Ib.: 5; y De Jesús 2012: 32, 58.

${ }^{86}$ De Jesús 2012: 58, 77, 78; y Van Deusen 2012a: 136-137. Por ejemplo, en una ocasión señaló lo siguiente: "fueron tantos los ahogos que me vinieron de que me enviaron unas y otras que les guisara que les hiciera esto y aquello y luego del convento que basta para ocuparlo todo y como yo ando con ansias de ir donde está el señor y con estas cosas me quitan el poco tiempo que me queda, fue un día trabajosísimo para mí» (De Jesús 2012: 31).
} 
ejercicio en la Sierva de Dios Úrsula, irse a la enfermería, a servir a las enfermas, y hacerles las camas, y a lavarles la ropa, y trapos de apostemas asquerosas; y si sentía repugnancia, se los entraba en la boca». ${ }^{87}$ En este sentido, en contraposición a las nociones negativas que imperaban sobre los cuerpos negros, Úrsula de Jesús le otorgó un significado distinto al suyo, pues lo exaltó como una de las principales virtudes de su nueva identidad cristiana. ${ }^{88}$

Su labor intercesora, sus deberes como donada y las mortificaciones que infligía sobre su cuerpo, además de garantizar la salvación de las almas del purgatorio, le permitían salvar su propia alma, una de sus principales preocupaciones. Probablemente, como señala Larissa Brewer-García, Úrsula de Jesús sentía la necesidad de conciliar las desigualdades que existían en la sociedad colonial con la idea de que todos eran iguales ante Dios. ${ }^{89}$ Ella tenía la incertidumbre de si le correspondía tener un lugar en el cielo o si, al igual que en la tierra, existirían jerarquías celestiales que la terminarían ubicando en el infierno o en el purgatorio por su negritud. Estas ansias son expresadas en la pregunta que le realizó a la negra María Bran que se le apareció en una de sus visiones: «la vi vestida de una alba, la negra dijo que había estado en el purgatorio por su condición. Dije que si las negras iban así al cielo. Dijo que como fuesen agradecidas y tuviesen atención a los beneficios y le diesen gracias por ellos las salvaba por su gran misericordia». ${ }^{90}$ Sin embargo, paradójicamente, ella encuentra en su negritud consuelo, pues creía que, como le había contado una de las negras que se le apareció en sus visiones, sus penas en el purgatorio serían menores si realizaba muchos trabajos en vida. Al incorporar esta idea en su discurso, Úrsula de Jesús rescató y revaloró la labor de los negros en la sociedad colonial, pues para ella «en esta [vida] quien más trabajare lo pasará mejor allá». ${ }^{91}$

\footnotetext{
${ }^{87}$ Anónimo 2012a: 140.

${ }^{88}$ Brewer-García 2013: 268.

${ }^{89}$ Ib.: 38.

${ }^{90}$ De Jesús 2012: 4.

${ }^{91}$ Ib.: $7,92$.
} 
En este sentido, la construcción de su identidad de mística negra se da a partir del reconocimiento de la exclusiva oportunidad que su negritud le concedía de llevar la imitación de Cristo al extremo. Es decir, la misma experiencia colonial que la identificó como esclava, que consideró su cuerpo negro como sinónimo de salvajismo, presencia del demonio e incapacidad de alcanzar una espiritualidad admirable, es la misma que le permitió construir una nueva identidad. Úrsula de Jesús señalaba en su Diario Espiritual que, al morir, "a cada uno le pedían cuenta conforme al talento que se le ha dado, que al donado como al donado que al negro como a negro se le pide cuenta de los diez mandamientos; más que al Religioso le corrían muchas más obligaciones». ${ }^{92}$ Sin embargo, ella, siendo negra, asumía muchas más obligaciones, tanto laborales como espirituales, que las religiosas. De esto no solo da cuenta su Diario Espiritual, en donde retrata su vida piadosa y su admirable espiritualidad, sino también las biografías que se escribieron sobre ella. En estas, se le compara con la Sibila de Cumas por sus dones de profecía, con un rey mago por su sabiduría y se le define como «Esposa muy querida del altísimo" por su exquisita experiencia mística. ${ }^{93}$

A pesar de que, en teoría, las monjas de velo negro ocupaban la parte superior de la jerarquía social y del coro del monasterio — pues la ubicación reflejaba la cercanía a Dios_-, en realidad estaban «asidas a estas cosas transitorias, eran vanas e no muriendo en esta vida hay mucho en la otra». ${ }^{94}$ Por el contrario, Úrsula de Jesús, aun ubicándose en la parte inferior de la jerarquía social y étnica, se dedicaba por completo al servicio de Dios y practicaba valores morales elevados, lo cual le garantizaba un lugar en el cielo y, en vida, le concedió un sitio en el coro junto a las monjas de velo negro. ${ }^{95}$ Por consiguiente, en el texto, enfatizó que a personas como ella, "que se mortifican», les esperaba «muy buen pasaje», y da cuenta de que, para beneficio suyo, las jerarquías sociales se encontraban

92 Ib.: 61 .

${ }^{93}$ Anónimo 2012a: 134. La Sibila de Cumas es una deidad de la mitología griega y romana capaz de conocer lo que depara en el futuro.

${ }^{94}$ De Jesús 2012: 54.

${ }^{95}$ Fernández 1997: 439; De Jesús 2012: 54; y Van Deusen 2012a: 59-60, 130. 
invertidas en el cielo. ${ }^{96}$ Por ejemplo, en una de las visiones narradas en su diario, describe a un fraile franciscano negro que se le apareció como alguien lindo y hermoso, pues estaba en la gracia de Dios por haber guardado en vida las reglas de la religión y por haber cumplido con lo que le mandaban. En esa misma narración, retrató a un fraile «blanco» como abominable y de hábito inmundo, pues había vivido cómodo, no había querido obedecer y no había servido a su comunidad. ${ }^{97}$ Estas visiones contrapuestas reflejan la propuesta central del Diario Espiritual: los negros, a pesar de ser considerados personas con un grado menor de humanidad, viles y endemoniadas, tenían una oportunidad excepcional, con sus cuerpos y su trabajo, para alcanzar más perfectamente la unión mística con Dios y, por consiguiente, la vida eterna.

\section{CONCLUSIONES}

Como se ha podido observar a lo largo de este artículo, la escritura de este texto místico le permitió construir su nueva identidad como sujeto católico. Úrsula de Jesús dejó de verse a través del lente con el que sociedad colonial la categorizaba y encontró la manera de ser una buena cristiana sin perder los atributos de su negritud. Así, se permitió rebatir los modelos de santidad existentes que solo consideraban la santidad de los afrodescendientes si se ceñían a las virtudes católicas imperantes, en una suerte de blanqueamiento espiritual. ${ }^{98}$ Este blanqueamiento era visto por Úrsula de Jesús como innecesario, pues los negros como ella se encontraban mucho más cercanos a Dios que cuantiosos frailes y monjas blancas que le dieron por completo la espalda. Su nueva identidad surge a partir del diálogo con su experiencia colonial; al nutrirse de ella, fue capaz de influenciar, con su misticismo negro, a instituciones como el monasterio de Santa Clara. Este cedió ante sus demandas de dejar

${ }^{96}$ De Jesús 2012: 54.

${ }^{97}$ Ib.: 113. Esto señalaba Úrsula de Jesús sobre el fraile: «desde el punto que murió con grandísimo peso había descendido a los infiernos que allá le aguardaban con terribles calderones [d] onde estaría para siempre» (De Jesús 2012: 10).

98 Brewer-García 2013: 219. 
memoria, a través de la escritura de un texto espiritual, de su experiencia de negra en una sociedad colonial.

El Diario Espiritual refleja el miedo que sentía Úrsula de Jesús de quedar en el olvido, como la esclava Luisa quien, a pesar de haber servido mucho tiempo en el convento, no tenía a nadie que la recordara o intercediera por ella. ${ }^{99}$ Por medio de la escritura, Úrsula de Jesús estaba remediando esta posibilidad y aparentemente lo logró, pues cinco meses después de su muerte, una parda, Francisca de la Cruz, solicitó a la abadesa profesar como donada «con el ejemplo de la Madre, Úrsula de Christo». ${ }^{100}$ Su éxito reside, además, en que su texto quedó custodiado por las clarisas alrededor de cuatro siglos y, como consecuencia, su vida y su espiritualidad se inmortalizaron en la historia y han ayudado a releer la experiencia de los afrodescendientes en la etapa colonial. La mayor parte del conocimiento que se tiene sobre los afrodescendientes se basa solo en documentos elaborados desde la oficialidad, por funcionarios coloniales obsesionados por categorizar a la población y que, por consiguiente, omitieron por completo las experiencias particulares que el momento colonial suscitó. ${ }^{101}$ Por el contrario, el Diario Espiritual es una fuente valiosa que nos permite acceder a ese sistema alternativo que existió en la época colonial, aquel creado por los afrodescendientes frente a las diversas identidades otorgadas y, sobre todo, es una fuente de memoria de las vidas de Úrsula de Jesús y de otras negras que tuvieron cabida en su narración.

\section{BIBLIOGRAFÍA}

Aguirre, Carlos. 2005. Breve historia de la esclavitud en el Perú. Lima: Fondo Editorial del Congreso del Perú.

Arenal, Electa y Stacey Schlau. 1990. «Stratagems of the Strong, Stratagems of the Weak: Autobiographical Prose of the Seventeenth-Century Hispanic Convent». Tulsa Studies in Women's Literature. Vol. 9, núm. 1: 25-42.

Anónimo. 2012a. «Breve biografía de Úrsula de Jesús escrita por una clarisa, contemporánea de Úrsula». En Van Deusen, Nancy (ed.). Las almas del purgatorio: el

\footnotetext{
${ }^{99}$ De Jesús 2012: 7, 79.

${ }^{100}$ Van Deusen 2012a: 25.

${ }^{101}$ Cahill 1994: 340; y Scott 2000: 24.
} 
diario espiritual y vida anónima de Úrsula de Jesús, una mistica negra del siglo XVII. Lima: Pontificia Universidad Católica del Perú, pp. 131-196 [disco compacto]. 2012b. «Transcripción modernizada de la Vida de Úrsula de Jesús, escrita por un franciscano anónimo». En Van Deusen, Nancy (ed.). Las almas del purgatorio: el diario espiritual y vida anónima de Úrsula de Jesús, una mistica negra del siglo XVII. Lima: Pontificia Universidad Católica del Perú, pp. 1-66 [disco compacto].

Araya, Alejandra. 2010. «La mística y el corazón: una tradición de espiritualidad femenina en América colonial». Cuadernos de Literatura. Vol. 14, núm. 28: 132-155.

Arrelucea, Maribel. 2010. Género, estamentalidad y etnicidad en las estrategias cotidianas de las esclavas de Lima, 1760-1800. Tesis de Maestría de Historia. Lima: Universidad Nacional Mayor de San Marcos.

Bennett, Herman. 2003. Africans in Colonial Mexico: Absolutism, Christianity, and Afro- Creole Consciousness, 1570-1640. Bloomington: Indiana University Press. Bhabha, Homi. 1984. "Of Mimicry and Man: The Ambivalence of Colonial Discourse». Discipleship: A Special Issue on Psychoanalysis. Vol. 28: 125-133.

Borges, Celia. 2007. «Las hijas de Teresa de Ávila: espiritualidad mística entre mujeres de la Península Ibérica y del Brasil colonial». En Viforcos, María y Rosalva Loreto (coords.). Historias compartidas: religiosidad y reclusión femenina en España, Portugal y América, siglos XV- XVI. León: Universidad de León e Instituto de Ciencias Sociales y Humanidades Alfonso Vélez Pliego, 177-194.

Borja, Humberto. 2009. «Purgatorios y juicios finales: las devociones y la mística del corazón en el Reino de Nueva Granada». Historia Crítica. Edición especial: 80-100.

Bowser, Frederick. 1977. El esclavo africano en el Perú colonial. México, D. F.: Siglo XXI Editores.

Brewer-García, Larissa. 2013. Beyond Babel: Translations Of Blackness In Colonial Peru And New Granada. Tesis de doctorado. Pennsylvania: University of Pennsylvania.

Burns, Kathryn. 2008. Hábitos coloniales: Los conventos y la economía espiritual del Cuzco. Lima: Instituto Francés de Estudios Andinos y Quellca. https://doi. org/10.4000/books.ifea.5951

Bynum, Caroline. 1987. Holy Feast and Holy Fast. Berkeley: University of California Press.

Cahill, David. 1994. "Colour by Numbers: Racial and Ethnic Categories in the Viceroyalty of Peru, 1532-1824». Journal of Latin American Studies. Vol. 26, núm. 2 (mayo): 325-346. https://doi.org/10.1017/s0022216x00016242

Camba, Úrsula. 2008. Imaginarios ambiguos, realidades contradictorias: conductas y representaciones de los negros mulatos novohispanos, siglos XVI y XVII. México, D. F.: El Colegio de México. 
Certeau, Michel de. 1996. La invención de lo cotidiano. México, D. F.: Universidad Iberoamericana.

Córdova y Salinas, Diego de. 1957. Crónica franciscana de las provincias del Perú. México, D. F.: Editorial JUS, 6 vols.

Cussen, Celia. 2014. Black Saint of the Americas: the life and afterlife of Martin de Porres. Nueva York: Cambridge University Press. https://doi.org/10.1017/ CBO9781139540599

De Jesús, Úrsula. 2012. «Transcripción original del diario espiritual de Úrsula de Jesús». En Van Deusen, Nancy (ed.). Las almas del purgatorio: el diario espiritualy vida anónima de Úrsula de Jesús, una mistica negra del siglo XVII. Lima: Pontificia Universidad Católica del Perú, pp. 1-130 [disco compacto].

Fernández, Amaya. 1997. La mujer en la conquista y la evangelización en el Perú (Lima, 1550-1650). Lima: Pontificia Universidad Católica del Perú.

Glave, Luis. 1998. De rosas y espinas: economía, sociedad y mentalidades andinas, siglo XVII. Lima: Instituto de Estudios Peruanos y Banco Central de Reserva del Perú. Graubart, Karen. 2009. «The Creolization of the New World: Local Forms of Identification in Urban Colonial Peru, 1560-1640». Hispanic American Historical Review. Vol. 89, núm. 3: 471-499. https://doi.org/10.1215/00182168-2009-003 . 2012. «So color de una Cofradía: Catholic Confraternities and the Development of Afro-Peruvian Ethnicities in Early Colonial Peru». Slavery \& Abolition. Vol. 33, núm. 1: 43-64. https://doi.org/10.1080/0144039x.2011.606620 . 2013. «Lazos que unen. Dueñas negras de esclavos negros en Lima, siglos XVI-XVII». Nueva corónica. Vol. 2: 625-640.

Hünefeldt, Christine. 1988. Mujeres, esclavitud, emociones y libertad: Lima, 18001854. Lima: Instituto de Estudios Peruanos.

Ibsen, Kristine. 1999. Women's Spiritual Autobiography in Colonial Spanish America. Gainesville: University Press of Florida.

Jouve-Martín, José. 2005. Esclavos de la ciudad letrada: esclavitud, escritura y colonialismo en Lima (1650-1700). Lima: Instituto de Estudios Peruanos.

Lavrín, Asunción. 2007. «Devocionario y espiritualidad en los conventos femeninos novohispanos: siglos XVII y XVIII». En Viforcos, María y Rosalva Loreto (coords.). Historias compartidas: religiosidad y reclusión femenina en España, Portugal y América, siglos XV-XVI. León: Universidad de León e Instituto de Ciencias Sociales y Humanidades Alfonso Vélez Pliego, 149-162.

Lévano, Diego. 2002. «De castas y libres: Testamentos de negras, mulatas y zambas en Lima Borbónica, 1740-1790». En O’Phelan, Scarlett. Etnicidad y Discriminación Racial en la Historia del Perú. Lima: Pontificia Universidad Católica del Perú, Instituto Riva-Agüero y Banco Mundial, vol. 2, 127-145.

Loreto, Rosalva. 2002. «Escrito por ella misma. Vida de la Madre Francisca de la Natividad (1630)». En Loreto, Rosalva y Asunción Lavrín (eds.). Monjas y 
beatas: la escritura femenina en la espiritualidad barroca novohispana, siglos XVII y XVIII. México, D.F.: Archivo General de la Nación 24-66.

Loreto, Rosalva y Sonya Lipsset-Rivera. 2002. «The Devil, Women and The Body in Seventeenth-Century, Puebla Convents». The Americas. Vol. 59, núm. 2: 181-199. https://doi.org/10.1353/tam.2002.0110

Mannarelli, María. 1999. Hechiceras, beatas, expósitas: Mujeres y poder inquisitorial en Lima. Lima: Congreso del Perú.

Martínez i Álvarez, Patricia. 2004. «La oralidad femenina en el texto escrito colonial: Úrsula de Jesús». Revista Andina. Núm. 38: 201-223.

McKinley, Michelle. 2012. «Till Death Do Us Part: Testamentary Manumission in Seventeenth-Century Lima, Peru». Slavery \& Abolition. Vol. 33, núm. 3: 381-401.

Mezan, Leila. 2007. «Biografías y autobiografías de mujeres ejemplares: los escritos de conciencia de la madre Jacinta de sao José y las prácticas religiosas femeninas en el Brasil colonial». En Viforcos, María y Rosalva Loreto (coords.). Historias compartidas: religiosidad y reclusión femenina en España, Portugal y América, siglos $X V$ - XVI. León: Universidad de León e Instituto de Ciencias sociales y Humanidades Alfonso Vélez Pliego, 127-148.

Millar, René. 2000. Misticismo e Inquisición en el Virreinato peruano: los procesos a los Alumbrados de Santiago de Chile. Santiago: Universidad Católica de Chile.

Mujica, Ramón. 2001. Rosa Limensis: Mistica, política e iconografía en torno a la patrona de América. Lima: Instituto Francés de Estudios Andinos, Fondo de Cultura Económica y Banco Central de Reserva del Perú.

Myers, Kathleen. 2003. Neither Saints nor Sinners: Writing the Lives of Women in Spanish America. Nueva York: Oxford University Press. https://doi.org/10.1093/ acprof:oso/9780195157239.001.0001

O’Toole, Rachel. 2012. «Peligro en el convento: demonios coloniales, indias idólatras, y negras hechiceras en Santa Clara (Trujillo del Perú)». Tempus: revista de historia. Vol. 1, núm.1: 149-186.

Osorio, Alejandra. 2008. Inventing Lima: Baroque Modernity in Peru's South Sea Metropolis. Nueva York: Palgrave Macmillan. https://doi. org/10.1057/9780230612488

Pignano, Giovanna. 2015. Entre quehaceres conventuales y arrebatos misticos: el diario de Úrsula de Jesús (Lima, siglo XVII). Tesis de Licenciatura en Historia. Lima: Pontificia Universidad Católica del Perú.

Rubial, Antonio. 2004. «Santos para pensar. Enfoques y materiales para el estudio de la hagiografía novohispana». Prolija Memoria: estudios de cultura virreinal. Vol. 1, núm. 1: 121-146.

Ruiz, Javiera. 2010. «Recogidas, virtuosas y humildes. Representaciones de las donadas en el monasterio de la Encarnación de Lima, siglo XVII». En Araya, 
Alejandra y Jaime Valenzuela (eds.). América Colonial. Denominaciones, clasificaciones e identidades. Santiago: RIL editores, 235-255.

Sánchez, José Luis y Luis Rodríguez. 2000. Los siglos XVI-XVII: cultura y vida cotidiana. Madrid: Editorial Síntesis.

Scott, James. 2000. Los dominados y el arte de la resistencia: discursos ocultos. México, D. F.: Ediciones Era.

Tardieu, Jean-Pierre. 1997. Los negros y la Iglesia en el Perú: siglos XVI-XVII. Quito: Centro Cultural Afro-Ecuatoriano y Ediciones Afroamérica, 2 vols.

Van Deusen, Nancy. 1999. «Manifestaciones de la religiosidad femenina en el siglo XVII: las beatas de Lima». Histórica. Vol. 23, núm.1: 47-78. . 2007. «El cuerpo como libro viviente (Lima, 1600-1640)». Histórica. Vol. 31, núm. 1: 11-57. . 2012a. «El mundo de Úrsula de Jesús». Las almas del purgatorio: el diario espiritual y vida anónima de Úrsula de Jesús, una mística negra del siglo XVII. Lima: Pontificia Universidad Católica del Perú, 15-160. . 2012b. "The Lord Walks Among the Pots and Pans" Religious Servants of Colonial Lima». En Bryant, Sherwin; Vinson III, Ben y Sarah O’Toole (eds.). Africans to Spanish America: Expanding the Diaspora. Urbana: University of Illinois Press, 136-160.

(ed.). 2012c. Las almas del purgatorio: el diario espiritual y vida anónima de Úrsula de Jesús, una mistica negra del siglo XVII. Lima: Pontificia Universidad Católica del Perú.

Vargas, Rubén. 1984. Historia del Santo Cristo de los Milagros. Lima: Centro de Proyección Cristiana.

Vega, Walter. 2001. «Manifestaciones religiosas tempranas: Cofradías de negros en Lima. Siglo XVI». Historia y Cultura. Vol. 24: 113-122.

Velázquez, María. 2006. Mujeres de origen africano en la capital novohispana, siglos XVII y XVIII. México, D. F.: Instituto Nacional de Antropología e Historia, Universidad Nacional Autónoma de México.

Weinstein, Donald y Rudolph Bell. 1982. Saints \& Society. Chicago: University of Chicago Press.

Recepción: 30/III/2017 Aceptación: 11/VII/2017 